\section{INTERFERON INDUCTION IN MICE BY ORAL ADMINISTRATION OF K-582, A NEW PEPTIDE ANTIBIOTIC}

Sir:

K-582 isolated from a culture filtrate of Metarhizium anisopliae is a new basic peptide antibiotic consisting of 7 amino acids, i.e. arginine, threonine, hydroxyarginine, tyrosine, ornithine and $1 y \sin ^{1,2)}$. This antibiotic was first isolated by its inhibitory effect on the growth of Candida albicans and other yeasts at the concentrations of $1 \sim 10 \mu \mathrm{g} / \mathrm{ml}^{11}$. Later the same effect on the growth of viruses such as polio, influenza, and Newcastle disease virus (NDV) was noticed although at higher concentrations of $100 \sim 500 \mu \mathrm{g} /$ $\mathrm{ml}^{1}$. Furthermore, growth inhibition of experimental tumors such as Ehrlich carcinoma, Sarcoma 180 and $\mathrm{SN}-36$ in mice were noted with this antibiotic $^{1)}$, although the mechanisms of these effects remain unclear.

Since the antiviral ${ }^{3)}$ and antitumor ${ }^{4)}$ effects of poly I: C, an interferon (IFN) inducer, were explained by IFN induced in the body of animals, it was felt that some biological activities of K-582 could probably be explained by K-582 induced IFN. Thus we investigated the IFN inducing activity of K-582 in mice.

Six to 8 week old male BALB/c mice obtained from the Institute for Experimental Animals, Tohoku University School of Medicine, were used for the IFN induction experiments. K-582, supplied by Kakenyaku Kako Co., Ltd. (Tokyo, Japan), was dissolved in sterile $0.01 \mathrm{M}$ phosphate buffered saline (PBS), pH 7.2, and orally given to these mice. The effect when the antibiotic was given by other routes will appear elsewhere.

The antiviral activity of the mouse serum was determined by using the plaque reduction method on mouse L-929 monolayer cell cultures. Cells were grown in Eagle's minimum essential medium (MEM, Nissui Pharmaceutical Co., Ltd. Tokyo, Japan) supplemented with $10 \%$ calf serum (Flow Laboratories Inc., Maryland, U.S.A.) in microtiter plates (No. 3042, Falcon Plastics, California, U.S.A.). They were treated with 2 -fold dilutions of mouse serum for 24 hours at $37^{\circ} \mathrm{C}$, and challenged with the Indiana strain of vesicular stomatitis virus $(\mathrm{VSV})^{5)}$. The antiviral activity was expressed by the reciprocal of the highest dilution of test sample that reduced VSV plaques
Fig. 1. Serum interferon response of mice to varying amounts of K-582.

A single oral administration of the indicated concentration was given to male BALB/c mice and serum for interferon assay was obtained after 24 hours.

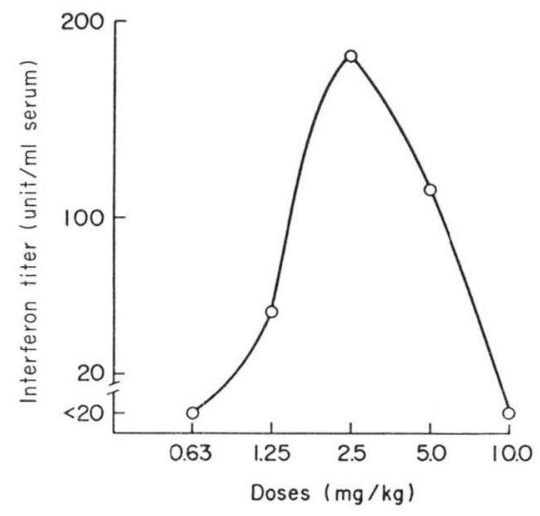

Fig. 2. Appearance and decay of induced interferon with time after oral administration of $2.5 \mathrm{mg} / \mathrm{kg}$ of K-582.

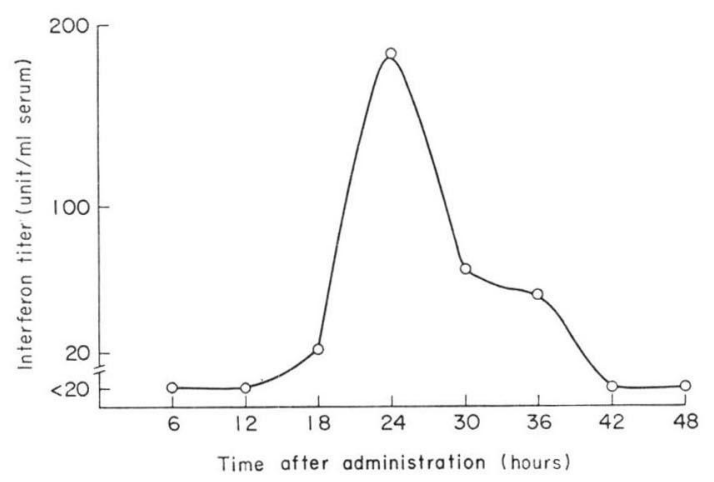

by $50 \%$. In conducting the plaque reduction assay with these mouse sera, IFN $\alpha / \beta$ was used as the standard. One unit in our assay system equaled almost 2 units of reference mouse IFN $\alpha$ / $\beta$ (Catalog No. 002-904-511, National Institute of Allergy and Infectious Disease, Bethesda, Maryland).

The first experiment was conducted to determine the dose response of K-582 on the induction of antiviral activity in mouse serum. Groups of three mice each were sacrificed after 24 hours, and the sera were pooled for the assay of antiviral activity. When the mice were given oral doses ranging from 0.63 to $10 \mathrm{mg} / \mathrm{kg}$ of K-582 dissolved in $0.5 \mathrm{ml}$ PBS and 24 hours sera were examined for antiviral activity, the optimal dose of $2.5 \mathrm{mg} /$ 
kg was obtained (Fig. 1). A low but definite antiviral titer was also induced with $1.25 \mathrm{mg} / \mathrm{kg}$ or $5 \mathrm{mg} / \mathrm{kg}$ doses (Fig. 1).

The time course of the induction of antiviral activity by $2.5 \mathrm{mg} / \mathrm{kg}$ oral dose of $\mathrm{K}-582$ was examined next (Fig. 2). Antiviral activity was detected as early as 18 hours after administration, reached a maximum titer of $180 \mathrm{unit} / \mathrm{ml}$ at 24 hours, and disappeared within 42 hours. Thus the response was delayed when compared with poly I: C and lipopolysaccharide but very close to those obtained with pyran copolymer, phosphomannan and other polysaccharides, and mitogens such as phytohemagglutinin ${ }^{6)}$.

In order to characterize the inhibitory activity found in mice serum 24 hours after oral admini-

Table 1. Properties of K-582 induced antiviral preparation from mice serum.

\begin{tabular}{|c|c|}
\hline Treatment & $\begin{array}{l}\text { IFN titer } \\
\text { (unit } / \mathrm{ml} \text { ) }\end{array}$ \\
\hline None & 120 \\
\hline \multicolumn{2}{|l|}{ Biological properties } \\
\hline Actinomycin $\mathrm{D}^{\mathrm{a}}$ & $<20$ \\
\hline Cycloheximide $^{\mathrm{b}}$ & $<20$ \\
\hline in WISH cells ${ }^{c}$ & $<20$ \\
\hline in $\mathrm{RK}-13$ cells ${ }^{\mathrm{c}}$ & $<20$ \\
\hline \multicolumn{2}{|l|}{ Physicochemical properties } \\
\hline Trypsin $^{\mathrm{d}}$ & $<20$ \\
\hline $\mathrm{pH} 2\left(4^{\circ} \mathrm{C}, 24 \text { hours }\right)^{\ominus}$ & 120 \\
\hline Heat $\left(56^{\circ} \mathrm{C}, 1 \text { hour }\right)^{\mathrm{f}}$ & $<20$ \\
\hline
\end{tabular}

a Actinomycin D, $5 \mu \mathrm{g} / \mathrm{ml}$, which inhibited cellular RNA synthesis by $95 \%$ as measured by incorporation of $\left[{ }^{3} \mathrm{H}\right]$ uridine, was added to the culture for 1 hour and was removed by multiple washing, and then the culture was treated with the preparation for 24 hours.

b Cycloheximide, $10 \mu \mathrm{g} / \mathrm{ml}$, which inhibited cellular protein synthesis by $90 \%$ as measured by incorporation of $\left[{ }^{14} \mathrm{C}\right]$ leucine, was treated together with the preparation for 24 hours.

c WISH cells or RK-13 cells were incubated with the preparation for 24 hours and challenged with VSV.

d The preparation was treated with $100 \mu \mathrm{g} / \mathrm{ml}$ of trypsin at $37^{\circ} \mathrm{C}$ for 1 hour.

- The preparation was dialyzed at $4^{\circ} \mathrm{C}$ for 24 hours against $0.1 \mathrm{M}$ glycin $-\mathrm{HCl}$ buffer at $\mathrm{pH} 2$ on a magnetic stirrer, and then dialyzed at $4{ }^{\circ} \mathrm{C}$ for 24 hours against PBS in the same way. The control preparation was dialyzed for 48 hours against PBS.

f The preparation was placed in a $56^{\circ} \mathrm{C}$ water bath, and cooled after 1 hour. stration of $2.5 \mathrm{mg} / \mathrm{kg}$ of K-582, the pooled serum was chromatographed on a Sephadex G-200 column. Fractions with antiviral activity appeared in the vicinity of the albumin fraction. Active fractions were pooled and concentrated in Visking cellulose tubes using negative pressure dialysis. This concentrate was again passed through a Sephadex G-100 column to estimate its molecular weight using aldolase, bovine serum albumin, ovalbumin and chymotrypsinogen as marker proteins. The major peak of antiviral activity was recovered by fractions in the 76,000dalton region.

Biological and physicochemical properties of this gel-filtrated preparation were examined next to see whether the antiviral activity could be ascribed to IFN or not (Table 1). The preparation did not induce antiviral states when mouse $\mathrm{L}$ cells were treated with either actinomycin $\mathrm{D}^{7)}$ or cycloheximide $^{8)}$, whereas in the absence of either inhibitor, an IFN titer of $120 \mathrm{unit} / \mathrm{ml}$ was obtained in the culture filtrate. In addition, the preparation did not show any antiviral activity either in human WISH cells or in rabbit RK-13 cells $^{9)}$, indicating to species-specificity. These results suggest that the antiviral activity of the preparation was due to IFN. Although the antiviral activity of the preparation was lost after trypsin treatment and heating at $56^{\circ} \mathrm{C}$ for 1 hour, the activity remained stable at pH 2 after 24 hours. This result contrasts with those reported for IFN $\gamma$.

K-582-induced IFN was also examined by the neutralization test using two types of anti-IFN sera, by the method previously described ${ }^{10)}$. A sheep antiserum against L-cell-IFN was used as anti-IFN $\alpha / \beta$ serum (Catalog No. G-024-501568, National Institute of Allergy and Infectious Disease, Bethesda, Maryland). This antiserum had a neutralizing titer of 600,000 per ml against $8 \sim 10$ reference units of IFN $\alpha / \beta$. Anti-IFN $\gamma$ serum, a rabbit antiserum against mouse IFN $\gamma$ induced by staphylococcal enterotoxin $\mathrm{A}^{11)}$, kindly supplied by J. A. Geogiades (University of Texas, Galveston, Texas, U.S.A.) was used. One milliliter anti-IFN $\gamma$ serum neutralized 30,000 units of IFN $\gamma$. Neutralization was expressed by the IFN titer remaining after a given interferonantibody treatment (Table 2). As noted in Table 2 , the antiserum against IFN $\alpha / \beta$ totally neutralized the antiviral activity of control IFN $\alpha / \beta$ which was kindly supplied by S. KoBAYASHI. Antiserum against IFN $\gamma$ also neutralized IFN $\gamma$ which 
Table 2. Neutralization of K-582-induced IFN by anti-IFN $\alpha / \beta$ and anti-IFN $\gamma$ antisera.

\begin{tabular}{lrcr}
\hline & \multicolumn{3}{c}{ IFN titer (unit/ml) } \\
\cline { 2 - 4 } Treatment & $\begin{array}{c}\text { K-582- } \\
\text { induced } \\
\text { IFN }^{\mathrm{a}}\end{array}$ & IFN $\alpha / \beta^{\mathrm{b}}$ & IFN $\gamma^{\mathrm{c}}$ \\
\hline None & 100 & 100 & 100 \\
Anti-IFN $\alpha / \beta^{\mathrm{d}}$ & 100 & $<2$ & 100 \\
Anti-IFN $\gamma$ & 100 & 100 & $<2$ \\
Combination of anti-sera 100 & $<2$ & $<2$ \\
\hline
\end{tabular}

a K-582-induced IFN was prepared to 2 unit/mg protein.

b IFN $\alpha / \beta$ produced in mouse $\mathrm{L}$ cells with Newcastle virus (NDV) was purified to the level of $2.2 \times 10^{6}$ unit $/ \mathrm{mg}$ protein, and was kindly supplied by S. KoBayashi (Toray Industries, Inc.).

- IFN $r$ was produced in BALB/c mouse spleen cell cultures with concanavalin $\mathrm{A}$ or in the serum which was collected 3 hours after intravenous challenge with BCG in BCG-presensitized mice.

d Equal volumes of antiserum and serial 2-fold dilutions of IFN were mixed, incubated for 30 minutes at $37^{\circ} \mathrm{C}$, and the remaining IFN activity was examined on $\mathrm{L}$ cells.

was produced either by concanavalin A stimulation of mouse spleen cell cultures ${ }^{12)}$ or in serum 3 hours after the intravenous challenge of $10^{7} \mathrm{BCG}$ cells (Japanese strain, Koseikai BCG Laboratory, Sendai, Japan) in BCG-presensitized mice ${ }^{13}$. However, K-582-induced IFN activity was not reduced after treatment with either anti-IFN $\alpha / \beta$ serum or anti-IFN $\gamma$. These results indicate that K-582 induced IFN is probably not a mixture of IFN $\alpha / \beta$ and IFN $\gamma$ (Table 2).

An experiment was conducted to determine the difference between K-582-induced IFN, IFN $\alpha / \beta$ and IFN $\gamma$, by examining the time course of the development of the antiviral state of mouse $\mathrm{L}$ cells after treatment (Fig. 3). All IFNs were applied at a concentration of $4 \mathrm{unit} / \mathrm{ml}$. At various hours after incubation at $37^{\circ} \mathrm{C}$, IFNs were removed, and the cells were challenged with VSV at a multiplicity of infection of 0.001. After 1 hour for viral adsorption, the cells were washed and overlaid with MEM containing $0.5 \%$ methylcellulose supplemented with $1 \%$ calf serum and incubated for 48 hours to develope viral plaques. As seen in Fig. 3, the L cell cultures treated with K-582-induced IFN developed substantial resistance as early as 6 hours after treatment, while IFN $\alpha / \beta$ and IFN $\gamma$ did not induce such resistance at 6 hours. IFN $\alpha / \beta$ took 12 hours and IFN $\gamma$,
Fig. 3. Development of antiviral state in mouse L cells when treated for various periods of time with 4 units of three different interferons.

O K-582-induced IFN; IFN $\alpha / \beta ; \triangle \operatorname{IFN} \gamma$

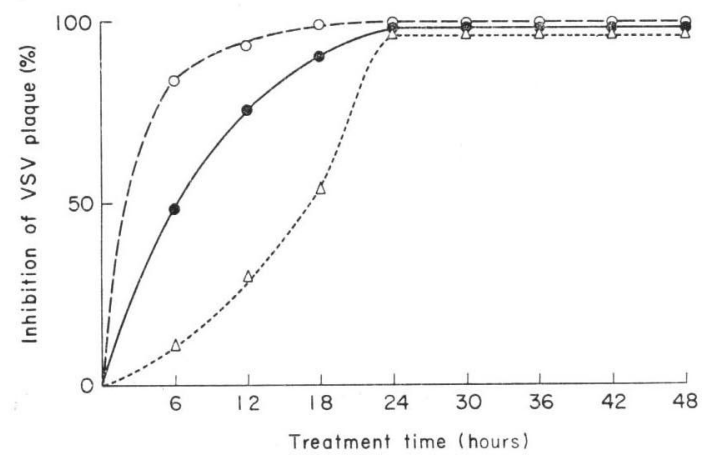

almost 24 hours to develop significant resistance. In tests of the kinetics of the development of antiviral state in $\mathrm{L}$ cells, it is known that antigenically different IFN displays different kinetics ${ }^{14)}$. Accordingly, the present data may indicate that $\mathrm{K}$ 582 induced an IFN that differs from IFN $\alpha / \beta$ and IFN $\gamma^{15)}$.

These results suggest that K-582 induces an antiviral substance very much related to IFN in mice serum after oral administration of an optimum dose of $2.5 \mathrm{mg} / \mathrm{kg}$. Recently, the induction of an IFN-like antiviral substance in human blood after oral administration of K-582 was also shown (S. ARAI, et al., personal communication). Thus further investigation of K-582 as an IFN-inducer may be warranted.

\section{Acknowledgments}

This work was supported in part by grants from the Ministry of Education, Science and Culture of Japan and from the Sendai Institute of Microbiology.

\section{Akira Sakai \\ TAKUSABURO EBINA \\ NAKAO IsHIDA}

Department of Bacteriology, Tohoku University School of Medicine, 2-1 Seiryo-machi, Sendai 980, Japan

(Received October 12, 1982)

\section{References}

1) Kondo, S.; N. Meguriya, H. Mogi, T. Aota, K. Miura, T. FujiI, I. Hayashi, K. Makino, M. 
Yамамото \& N. Nakajima: K-582, a new peptide antibiotic. I. J. Antibiotics 33: 533 542,1980

2) Kawauchi, H.; M. Tohno, Y. Tsuchiya, M. Hayashida, Y. Adachi, T. Mukai, I. Hayashi, S. Kimura \& S. Kondo: Studies on the structure of a novel peptide antibiotic, K-582. Int. J. Peptide Protein Res., in press.

3) Gresser, I.; M. G. Tovey, M. T. Bandu, C. MAURY \& D. BROUTY-BOYE: Role of interferon in the pathogenesis of virus diseases in mice as demonstrated by the use of anti-interferon serum. I. Rapid evolution of encephalomyocarditis virus infection. J. Exp. Med. 144: $1305 \sim 1315,1976$

4) Gresser, I.; C. Maury, M. T. Bandu, M. Tovey \& M. T. Maunoury: Role of endogenous interferon on the anti-tumor effect of poly I: $\mathrm{C}$ and statolon as demonstrated by the use of anti-mouse interferon serum. Int. J. Cancer 21: 72 77, 1978

5) Stewart, II, W. E.; W. D. Scott \& S.E. Sulkin: Relative sensitivities of viruses to different species of interferon. J. Virol. 4: 147 153, 1969

6) FINTER, N. B.: Interferon and Interferon Inducers. p. 45, North-Holland Publishing Company-Amsterdam. London/American Elsevier Publishing Co., Inc., New York, 1973

7) TAYLOR, J.: Inhibition of interferon action by actinomycin. Biochem. Biophys. Res. Commun. 14: $447 \sim 451,1964$

8) Dianzani, F.; C. E. Buckler \& S. Baron: Effect of cycloheximide on the antiviral action of interferon. Proc. Soc. Exptl. Biol. Med. 130:
519 523, 1969

9) Youngner, J. S. \& S. B. Salvin: Production and properties of migration inhibitory factor and interferon in the circulation of mice with delayed hypersensitivity. J. Immunol. 111: 1914 1922, 1973

10) Yamamoto, Y. \& Y. Kawade: Antigenicity of mouse interferons: Distinct antigenicity of the two $\mathrm{L}$ cell interferon species. Virology 103: $80 \sim 88,1980$

11) Osborne, L. C.; J. A. Gergiades \& H. M. JOHNSON: Classification of interferon with antibody to immune interferon. Cell. Immunol. 53: $65 \sim 70,1980$

12) Johnson, H. M.; G. J. Stanton \& S. Baron: Relative ability of mitogens to stimulate production of interferon by lymphoid cells and to induce suppression of the in vitro immune response. Proc. Soc. Exptl. Biol. Med. 154: 138 141, 1977

13) SAlvin, S.B.; J.S. Youngner \& W.H. Lederer: Migration inhibitory factor and interferon in the circulation of mice with delayed hypersensitivity. Infec. Immun. 7: 68 75, 1973

14) Dianzani, F.; L. Salter, W. R. Fleischman, Jr. \& M. ZUCCA: Immune interferon activates cells more slowly than dose virus-induced interferon. Proc. Soc. Exptl. Biol. Med. 159: 94 97, 1978

15) Chen, Y.S.; M. W. Stewart, E. Oleszak \& W. E. StewART, II: Heterogeneity of human IFN gamma preparations: Multiple forms of huIFN-gamma, of multiple non-alpha, non-beta huIFNs? Abstracts of the 2nd Annual International Congress for Interferon Research, III-3, San Francisco, 1981 